\title{
Arquitectura palatina del reino de Mallorea. Símbolos de poder para una efímera dinastía*
}

\author{
Joan Domenge MesquidA \\ Universitat de Barcelona \\ Departament d'Història de l'Art \\ domenge@ub.edu
}

\begin{abstract}
RESUMEN
Entre 1276 y 1343 Mallorca, el Rosellón y Montpellier constituyeron una Corona independiente de la aragonesa. A pesar de las tensiones derivadas de esta partición territorial, la nueva dinastía logró impulsar un programa constructivo -y artístico en general- de gran alcance, que se intensifica a partir del 1300 . La estabilidad política y económica, el dinamismo comercial y la implantación de una severa fiscalidad permitieron a los reyes de Mallorca, y en especial a Jaime II, crear una red de residencias, entre las que destacan los castillos de Perpiñán y Palma de Mallorca (la Almudaina, Bellver). Además de satisfacer las necesidades prácticas de una corte itinerante, con estos palacios se manifestaba simbólicamente el poder del nuevo reino. Los espacios de culto y representación, la originalidad tipológica del castillo de Bellver o el riguroso y calculado ceremonial que se regula en las Leges Palatinae manifiestan la voluntad de la vulnerable y dispersa Corona de crear, con todos los medios al alcance, una imagen de poder y prestigio. Si las ambiciones políticas de la Corona de Aragón acabaron triunfando, las promociones artísticas mallorquinas iban a pervivir como elocuentes testimonios de una dinastía efímera que procuró, con afán, crear los escenarios de su realeza en los que manifestarse con toda su dignidad.
\end{abstract}

Palabras clave: Corona de Mallorca, siglos XIII-XIV, arquitectura palatina, gótico mallorquín, castillo de Bellver, Leges Palatinae / Leyes Palatinas, ornamentos textiles, paños ricos, culto y representación, simbolismo artístico.

\section{Palatial architecture in The Kingdom of Mallorca. Symbols of power for a short-lived dynasty}

\begin{abstract}
Between 1276 and 1343, Mallorca, Roussillon and Montpellier constituted an independent kingdom separated from the Crown of Aragon. Even though conflicts arose from this territorial partition, the new ruling dynasty was able to carry out a noteworthy artistic and architectural agenda which became particularly intense after 1300. The kings of Mallorca, especially James II, created a network of royal residences including the castles of Perpignan and Palma de Mallorca (The Almudaina, Bellver). Several factors made this possible: the political and economic stability of the new kingdom, the intensity of its commercial activity, and the creation of a strong tax system. The new Majorcan palaces met the needs of the traveling court, and provided symbolic representation of power for the new kingdom. The new crown, while vulnerable and geographically scattered, needed to use all available means in order to project an image of power and prestige. This was also demonstrated through the creation of spaces of worship and representation, the originality of Bellver Castle, and the strict ceremonial procedures at court as
\end{abstract}

* Esta aportación se ha realizado en el marco del proyecto de investigación La corona de Aragón y las cortes septentrionales: contactos artísticos en época gótica (Ministerio de Economía y Competitividad, HAR2010-18498) que se lleva a cabo en el Departament d'Història de l'Art de la Universitat de Barcelona. 
regulated in the Leges Palatinae. In the end, the political ambitions of the Crown of Aragon triumphed, but Majorcan artistic endeavors survived. They still bear eloquent witness to a short-lived dynasty that eagerly sought to create a backdrop for its royalty and demonstrate its majesty.

Key words: Crown of Mallorca, 13th-14th centuries, palatial architecture, Majorcan Gothic, Bellver Castle, Leges Palatinae / courtly code, textile ornamentation, worship and representation, artistic symbolism.

Jaime I el Conquistador, en un solemne acto o acuerdo de partición de sus territorios (1262), decidió crear un reino para su hijo Jaime. El primogénito Pedro heredaría Aragón, Cataluña y Valencia, mientras el infante Jaime, que contaba diecinueve años, iba a recibir las Baleares, los condados del Rosellón y Cerdaña, el señorío de Montpellier y las baronías de Omelades - próxima a Montpellier- y Carlades, en Auvernia. Desde este acuerdo sucesorio, confirmado en el testamento del Conquistador de 1271 y aprobado formalmente por ambos infantes, éstos se convertían en procuradores y vicarios generales de sus respectivos territorios, para que, según indica la crónica de Muntaner, viviesen como señores con sus esposas e hijos y para que el rey pudiera comprobar el bon seny e el bon recapte e el bon regiment de cascuns, o sea, las capacidades de sus sucesores para el buen gobierno ${ }^{1}$.

La historiografía no ha dudado en subrayar la falta de visión política y estratégica del Conquistador al dividir sus territorios, partir una sólida Corona que había ampliado notablemente sus horizontes y crear un pequeño reino constituido por tierras disgregadas en un mar difícil de controlar y en medio de enemigos poderosos y absorbentes. Esta dispersión geográfica, sumada al descontento de los soberanos aragoneses por lo que consideraban una injusta amputación territorial, era presagio de una existencia precaria, espinosa, difícil, como no tardaría en confirmarse. Ese "frágil reino de cristal", esa "corona de espinas" nacía condenada a un desafortunado y trágico destino.

El reino independiente duraría apenas 75 años: los que transcurren desde la muerte de Jaime I en 1276 hasta 1343, cuando los territorios de Jaime III de Mallorca son usurpados por su cuñado Pedro el Ceremonioso, rey de Aragón, bajo el pretexto de incumplimiento de los deberes de vasallaje por parte del primero; se suceden luego las acciones bélicas, la muerte de Jaime en 1349 y la venta a Felipe de Valois de Montpellier y de los feudos languedocianos. Pero a pesar de las contrariedades vividas, en el último cuarto del siglo XIII se iniciaba una etapa singular de la historia de este nuevo reino soberano. Se emprendió un programa edilicio que las condiciones políticas y familiares adversas impidieron que despegara; no habían transcurrido todavía diez años desde que la Corona iniciara su andadura cuando Alfonso el Franco la

1 J.E. MARTÍNEZ FERRANDO, La tràgica història dels reis de Mallorca, Barcelona, 1960, pp. 16-26; M. DURLIAT, L'art en el regne de Mallorca, Mallorca, 1989 [Toulouse, 1962], p. 163. 
sometió nuevamente a Aragón (1285) y la paz no se vio restablecida hasta los últimos años de la centuria, con la restitución de los territorios a Jaime II de Mallorca ${ }^{2}$.

Será hacia 1300 , con la recuperación de la plena soberanía, cuando se den las condiciones para acometer un ambicioso plan edilicio que no deja de sorprender, dada la limitación territorial y los recursos de la Corona, para nada sobrantes. El plan se cimenta sobre una serie de medidas de reactivación económica cuyos resultados seguramente no fueron los esperados: estímulo al sector primario, creación de un sistema monetario propio, reformas arancelarias y empuje al desarrollo de una manufactura de paños de lana. Dichas medidas, sumadas a un programa de estructuración territorial y a la consecución de alianzas internacionales, reflejan la capacidad de Jaime II para el gobierno y la gestión de su reino ${ }^{3}$. La complementariedad económica -mercantil en las islas, industrial en los territorios continentales- y la diversidad sociológica y cultural ${ }^{4}$ son factores a considerar para comprender la vitalidad de una Corona que, como contrapartida de su pequeñez y dispersión, tenía una isla estratégicamente situada, un auténtico cap de creus, o sea, una encrucijada de rutas comerciales que favorecía la práctica de la mercadería, según el cronista Marsili ${ }^{5}$. La presión de una fiscalidad permanente -más intensa en los territorios insulares- va a ser decisiva para la financiación de un plan que atiende a las necesidades defensivas, residenciales y religiosas de la joven dinastía. Perpiñán y Ciutat de Mallorques, las capitales del reino, reflejan la ambición de dicho programa, al conservar los testimonios más monumentales de la arquitectura palatina, con la que Jaime II quiso mostrar ostensiblemente su poder y prestigiar a su dinastía ${ }^{6}$.

Hay que lamentar la pérdida por completo del castillo de Montpellier, la mejor construcción heredada por la joven Corona, pues acababa de ser remodelada por el Conquistador. Su desaparición impide valorar la probable influencia que tuvo este edificio en los que Jaime II emprendería en las otras capitales de su reino; el monarca lo conocía bien por haber residido allí siendo infante y por haber realizado en él algunos actos públicos, una vez rey. Los documentos referidos al castillo mencionan una torre, una capilla de dimensiones notables - con estimables reliquias de la Santa Cruz y de las Espinas que habían pertenecido a Philippe le Bel-, una gran sala, las cámaras del rey y la reina, la recámara y la despensa (rebost); estancias que al parecer se articulaban en torno a un patio ${ }^{7}$.

2 Para una síntesis histórica del periodo, cf. A. MAS, "La problemàtica evolució política del regne privatiu”, E. BELENGUER (dir.), Història de les Illes Balears, Barcelona, 2004, vol. II, pp. 51-83.

3 A. RIERA, "Mallorca 1298-1311, un ejemplo de planificación económica en la época de plena expansión", Estudios históricos y documentos de los archivos de Protocolos, V (1977), pp. 199-243; D. ABULAFIA, Un emporio mediterráneo. El reino catalán de Mallorca, Barcelona, 1996.

4 P. CATEURA, El Regne esvaït: desenvolupament econòmic, subordinació política, expansió fiscal (Mallorca, 1300-1335), Palma de Mallorca, 1998, pp. 133-134. Como observa el autor, "el reino de Mallorca constituye en si mismo un auténtico laboratorio en el que se interrelacionan la debilidad política, el desarrollo comercial y la maduración de la fiscalidad" (p. 139).

5 J.M. QUADRADO, Historia de la conquista de Mallorca. Crónicas inéditas de Marsilio y de Desclot, Palma de Mallorca, 1850, p. 22.

6 F. ESPAÑOL, Els escenaris del rei. Art i monarquia a la Corona d'Aragó, Manresa, 2001, p. 21.

7 M. DURLIAT, op. cit., 1989, pp. 154-155. 


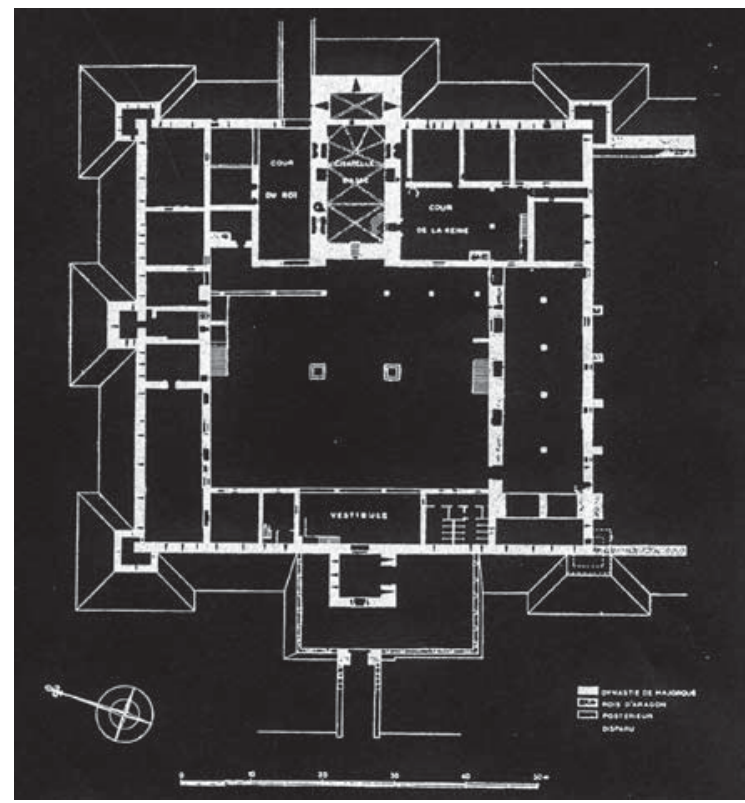

Fig. 1. Perpiñán. Palacio de los Reyes de Mallorca, planta.

En Perpiñán sobrevive el Palacio de los Reyes de Mallorca, o castrum regii perpiniani-si atendemos a la manera como se cita en documentos de época- alterado y transformado por los embates de su historia; no obstante algunas partes esenciales de la que tal vez fuera principal residencia de la corte mallorquina conservan su estructura original y todavía pueden evocar su momento de esplendor. Dado que los soberanos residieron de manera más continua en esta ciudad y que la administración real estuvo controlada por funcionarios del Rosellón ${ }^{8}$, no es de extrañar que se hable, en términos genéricos, de la corte de Perpiñán para aludir a la Corona de Mallorca. En Palma se conservan la Almudaina, viejo alcázar islámico remodelado por Jaime II, y el castillo de Bellver, construido de nueva planta también por deseo del mismo rey. Su hijo Sancho se encargaría de continuar las múltiples obras iniciadas por su padre, insaciable promotor. No tiene que sorprender la reforma de un castillo heredado del pasado musulmán. Jaime I, al empuñar la espada para instigar a la conquista de Mallorca, había dejado sentenciado que su propósito era "convertir" o "destruir" a quienes no profesaban la fe de Nuestro Señor". Con criterio pragmático en materia de arquitectura, "convertiría" las fábricas musulmanas en espacios, profanos y religiosos, adaptados a las exigencias de la cultura cristiana y de los nuevos modos de vida que se impusieron en la isla tras la conquista de 1229. Pero el proceso sería largo y

8 P. CATEURA, op. cit., 1998, pp. 134-135.

9 F. SOLDEVILA (ed.), Les quatre grans cròniques, Barcelona, 1971, p. 32. 
lento; tan solo paulatinamente se irían reemplazando los viejos edificios musulmanes para así borrar un pasado con el que se quería romper, al menos ideológicamente ${ }^{10}$.

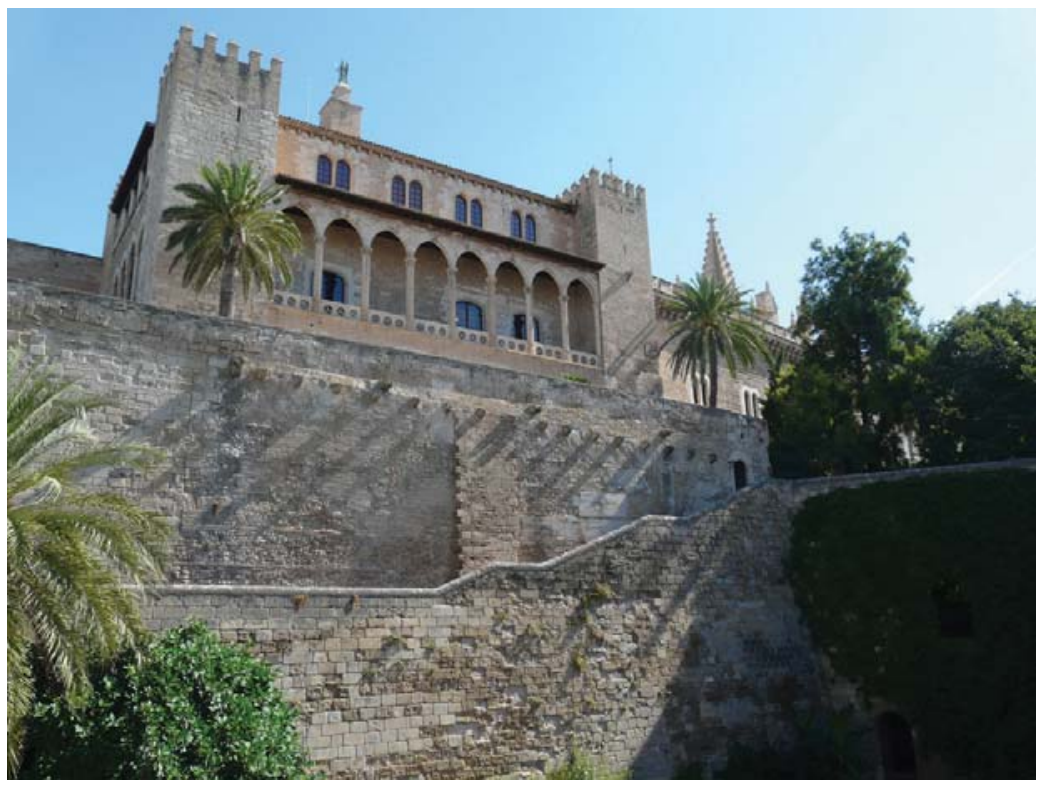

Fig. 2. Palma de Mallorca. Castillo de la Almudaina, exterior.

Sin embargo el calculado y sistemático proyecto constructivo de Jaime II rebasa los límites de las capitales continental e insular. En lo que concierne a la isla, su programa contemplaba la recuperación de todas cuantas fortificaciones fueran útiles para la defensa del nuevo reino, así como la creación de una red de residencias "rurales", secundarias si se quiere, respecto a la mayor magnificencia de los castillos urbanos. Los viejos husun, fortificaciones islámicas, cuyo valor defensivo se beneficiaba de los parajes escarpados en que se ubicaban, fueron consolidados y mínimamente acondicionados a las nuevas exigencias de la guarnición que se encargaba de su custodia: castellanos, sirvientes y presbíteros ${ }^{11}$. Son dignos de mención el castillo del rey, en Pollença, que protegía el norte de la isla; el de Santueri, en el municipio de Felanitx, que mira hacia África y defendía la isla de las agresiones del sur y el castillo de Alaró, en el interior, que es alabado por las crónicas como bastión inexpugnable ${ }^{12}$.

10 J. DOMENGE, "Les residències dels reis a Mallorca", Un Palais dans la ville. Le Palais des Rois de Majorque à Perpignan. Colloque international, Perpignan, en prensa. En esta aportación desarrollamos más extensamente algunos aspectos tratados aquí de manera concisa.

11 J. MERINO, Llibre dels castells, Palma de Mallorca, 2002, pp. 17-19.

12 De manera concisa, la crónica de Pere Marsili recuerda que " $E$ ha aquesta ciutat de fora tres casteyls molt forts asseguts e sitiats en molt altas montanyas: lo un contra la part de Cathalunya lo qual es dit e nomenat de Polensa, l'altre contra la part de Affrica lo qual és apeylat de Santueri, altre dintre terra qui no e’s pot combatre lo qual és apeylat Alaró”. J.M. QUADRADO, op. cit., 1850, p. 24. 
Los soberanos quisieron disponer también de una serie de casonas en la part fora$n a$ (Sineu, Manacor, Valldemossa, el Teix), erigidas tal vez sobre estructuras preexistentes y que han llegado completamente transformadas por las vicisitudes históricas y los distintos fines a que se han destinado. Con estos palacios -así son mencionados en los documentos- se pretendía ejercer un mayor control sobre los territorios, dar cobijo a los representantes locales de la administración real y disponer de un alojamiento digno cuando se realizaban cacerías. Sus prominentes torres garantizaban la presencia simbólica del poder real sobre el territorio, al ser el elemento arquitectónicamente más relevante, con el que tan solo rivalizarían los campanarios de los templos. La torre del palacio de Sineu todavía impone su presencia sobre la villa, a pesar de que desde el siglo XVI la residencia real fuera legada a las monjas agustinas y progresivamente transformada en convento. Antiguos testimonios gráficos de Manacor revelan también la importancia de la torre palaciega, que en época moderna sería eclipsada por las moles de la iglesia parroquial y del convento de Santo Domingo. A pesar de la sobriedad que al parecer caracterizaba a estas casas rurales, merece la pena recordar que algunas habitaciones -tanto en Sineu como en las casas del Teix- fueron ornamentadas con pinturas salidas de la mano del pintor Perpinyà Bonaventura, el mismo artífice que se ocuparía de decorar el Castillo de Bellver ${ }^{13}$. No queda ni rastro de esta decoración, pero los pagos que recibe el pintor dejan suponer que se trataba de adornos sencillos -combinaciones geométricas, falsos despieces, orlas vegetales, cenefas, etc.- y de rápida ejecución.

Insistamos. Semejante despliegue edilicio en un reino pequeño y amenazado debe de responder, pues, a un plan concienzudamente diseñado que no pretende tan solo responder a las necesidades prácticas de una corte que tiene que surcar el mar para hacerse presente en sus dominios. La intención simbólica parece clara. El impulso nunca visto que reciben la arquitectura y las restantes expresiones artísticas a inicios del siglo XIV pretende reforzar la imagen y el prestigio de la joven dinastía. Tal vez la misma dispersión territorial del reino obligaba a multiplicar las iniciativas, para así manifestar, de forma eficaz y tangible, el nuevo poder en todas partes. Incluso da la impresión de que Jaime II y sus sucesores quisieron compensar la debilidad política y la vulnerabilidad del nuevo estado con una significativa y calculada producción de símbolos de poder. E. Mira recuerda que "la arquitectura del poder tiene casi siempre una intención de perpetuidad de si misma y del poder que simboliza. Tiene, con frecuencia, una realidad de pervivencia que va más allá de la vida de las personas que la diseñaron y para las que fue edificada e, incluso, más allá de las razones que llevaron a construirla". Ciertamente mueren las personas, se extinguen las dinastías, se dispersan y/o destruyen los bienes muebles -también expresión de su poder-, pero los edificios "suelen tener una vida más larga (...), son testimonio omnipresente y nos acompañan siempre en ese espacio de la simultaneidad histórica que es el espacio construido" ${ }^{14}$.

13 M. DURLIAT, op. cit., 1989, pp. 159, 162.

14 E. MIRA, "Lexant a part l'estil dels trobadors", G. TOSCANO (curador), La Biblioteca Real de Nápoles en tiempos de la dinastía Aragonesa, Valencia, 1998, p. 61. 
Si dicha intención late en el ambicioso programa acometido, en algunas obras se refleja de manera más convincente, como en los castillos urbanos, y particularmente en el de Bellver. También se hace del todo explícita en las Leges Palatinae, promulgadas por Jaime III en 1337, para organizar los servicios de la corte, la cancillería y el aparato financiero del reino ${ }^{15}$. El texto, una auténtica joya sobre el ritual de palacio, estaba pensado, entre otras razones, para impresionar a reyes y súbditos con una rigurosa, ordenada y magnificente etiqueta curial. Se regula hasta el más mínimo detalle, todos los movimientos de palacio están milimétricamente calculados y cada función o cargo se acota con la máxima precisión. Las palabras de Durliat, al fijar con precisión cuál fuera la intención del soberano al promulgar este texto, mantienen a nuestro entender toda su vigencia. Las Leges no nacen de una supuesta voluntad de reforma moral y política, ni tienen por objetivo una precoz exaltación del culto monárquico. "Representan en realidad un acto político, un esfuerzo remarcable en vistas a reforzar la autoridad y el prestigio de la realeza mediante la organización y mantenimiento de un brillante séquito, la institución de un gobierno mejor y de una administración más eficaz. El objetivo final es defender mejor el estado mallorquín contra sus divisiones internas y contra los peligros externos, siempre renacientes" 16 .

En una dirección similar se expresa B. Palacios al ver el origen de las Leges en "los viejos y nuevos temores" que acucian al pequeño reino. Desde su ascenso al trono, Jaime III vivió permanentemente en un clima de inseguridad, "con el temor a que por alguna omisión o incumplimiento, voluntario o involuntario, de sus obligaciones hacia la casa central, se viese desposeído de su reino". Seguramente guiado por sus consejeros comprendió que para esquivar este peligro era necesario "ordenar" bien la casa y corte mallorquinas, "es decir, dejar bien claro cuáles habían de ser las pautas de comportamiento que el rey y los cortesanos debían de observar en su política y en todos sus actos, hasta los más insignificantes, para demostrar que tal conducta era conforme al derecho establecido y a los principios ideológicos entonces imperantes en la cristiandad occidental". Como bien observa el autor, al fin "tantas y tan prudentes cautelas no sirvieron de mucho" 17 .

La lectura de estas ordenanzas permite imaginar cómo se vivía, o mejor dicho, cómo idealmente quería vivir Jaime III en los palacios edificados, en buena medida, por su abuelo; los registros de cuentas del Real Patrimonio revelan, en efecto, una corte más austera, menos impactante, de la que quería Jaime en su ordenamiento. A pesar de que las referencias explícitas a los lugares y escenarios de esta vida curial tan

15 Sobre el contenido de la Leges, contextualizado a partir de otros ordenamientos de la Corona de Aragón, cf. M. VANLANDINGHAM, Transforming the State. King, Court and Political Culture in the Realms of Aragon (1213-1387), Leiden-Boston-Köln, 2002.

16 M. Durliat añade que "manifiestan, en fin, un sentido de la justicia y de la mesura natural en un príncipe cristiano cultivado, instruido en los tratados jurídicos de la antigüedad y rodeado de hombres de leyes y de clérigos". (La traducción del catalán al castellano es nuestra). M. DURLIAT, "La cort de Jaume III de Mallorca (1324-1349) segons les Lleis Palatines", JAUME III REI DE MALLORCA, Lleis Palatines, Palma de Mallorca, 1991, v. 1, p. 20.

17 B. PALACIOS MARTÍN, "Estudio", El "Manuscrito de San Miguel de los Reyes" de las "Ordinacions" de Pedro IV, Valencia, 1994, pp. 22-23. 
meticulosamente pautada más bien brillen por su ausencia, volveremos a las Leyes para intentar "visualizar" algunos interiores de palacio.

\section{Espacios de culto y representación en los castillos de Perpiñán y de la Almudaina}

A pesar de sus distintos emplazamientos, orígenes y condicionantes, las dos residencias regias comparten características comunes que las hermanan y que revelan cómo una misma mente -incluso una misma mano- traza sus directrices. Nuestra aproximación puede cimentarse todavía en los rigurosos estudios de M. Durliat quien, basándose en una exhaustiva y atenta consulta documental, fija cronologías, nombra espacios, revela procedencias de materiales y descubre a artífices que simultanean ambos territorios. El análisis formal y arquitectónico también pone en evidencia su parentesco, especialmente el de las partes construidas bajo el impulso de Jaime II en torno a 1300.

El castrum regii Perpiniani empezó a edificarse antes de que Jaime fuera titular del reino, por el deseo de tener en el Rosellón su lugar habitual de residencia; la antigua sala condal era insuficiente para su corte y asimismo era impropio de un príncipe el tener que recurrir constantemente a la hospitalidad conventual ${ }^{18}$. El emplazamiento escogido fue el Puig del Rei, una colina de la ciudad englobada en el perímetro amurallado. Al ser una edificación de nueva planta no sorprende su regularidad: un recinto casi cuadrado con torres en los ángulos y también en tres de sus lados. En 1274 se tiene constancia de la realización de obras y cuando Jaime es despojado de su reino en 1285 ya moraba en el castillo. Pero este impulso inicial quedó truncado por el conflicto del rey de Mallorca con sus parientes de Barcelona y no se retomó hasta los últimos años del siglo, una vez firmada nuevamente la paz; entre 1295 y la muerte de Jaime II en 1311, el ritmo constructivo debió de ser muy intenso.

Distinta es la historia del castell reial de Mallorques ${ }^{19}$. Aquí se aprovecha el viejo alcázar islámico, lo que condicionará la estructura de la nueva residencia. A lo largo de todo el siglo XIII, al visitar la isla, los reyes se alojarán en las viejas dependencias sin remodelar - tal vez con las mínimas adaptaciones a les exigencias de unos monarcas cristianos-, o al menos no queda constancia de la realización de obras; incluso se servirán de la mezquita situada enfrente, sin tener necesidad -o recursos- para iniciar una nueva catedral con caracteres formales inequívocamente cristianos. La remodelación de la Almudaina se lleva a cabo durante la primera década del s. XIV, discurriendo paralelamente a las obras de Perpiñán y de Bellver. El impacto de esta intervención y de las múltiples alteraciones sufridas por el castillo a lo largo de la historia han dejado su huella en el edificio. No obstante quedan vestigios muy desdibujados

18 M. DURLIAT, op. cit., 1989, pp. 164-166.

19 Ibidem, pp.181-198; J. SASTRE, Els llibres d'obra del palau reial de l'Almudaina (1309-1314), Palma de Mallorca, 2001 [contiene la transcripción de los tres libros de obra conservados sobre el castillo y una aproximación al contenido de los mismos]; J. DOMENGE, "L'art gòtic a Mallorca", E. BELENGUER (dir.), op. cit., 2004, vol. II, pp. 246-248; M. BARCELÓ y G. ROSSELLÓ, La ciudad de Mallorca. La vida cotidiana en una ciudad mediterránea medieval, Palma de Mallorca, 2006, pp. 163-172. 
del primitivo recinto islámico -con un trazado aproximadamente rectangular- en el ángulo suroeste del actual complejo.

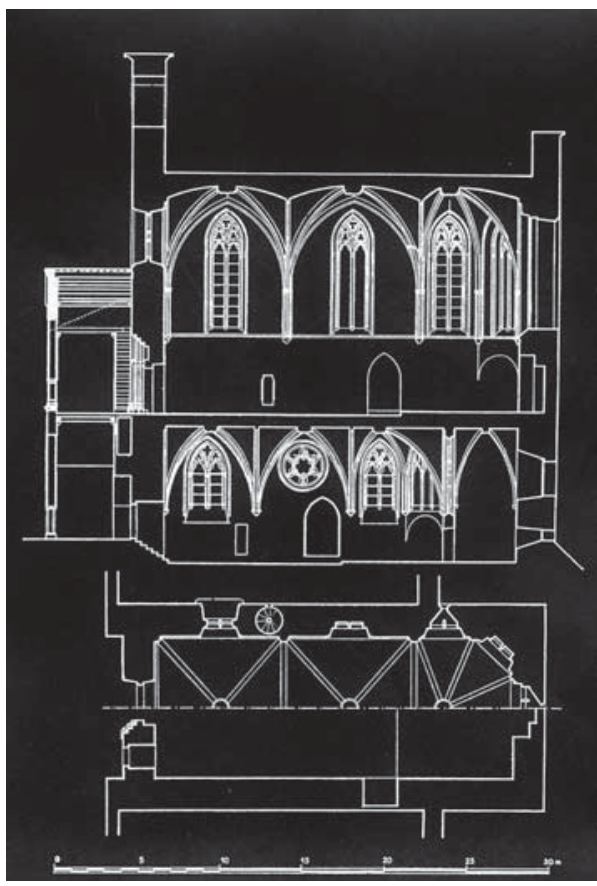

Fig. 3. Perpiñán. Palacio de los Reyes de Mallorca, sección transversal de las capillas superpuestas.

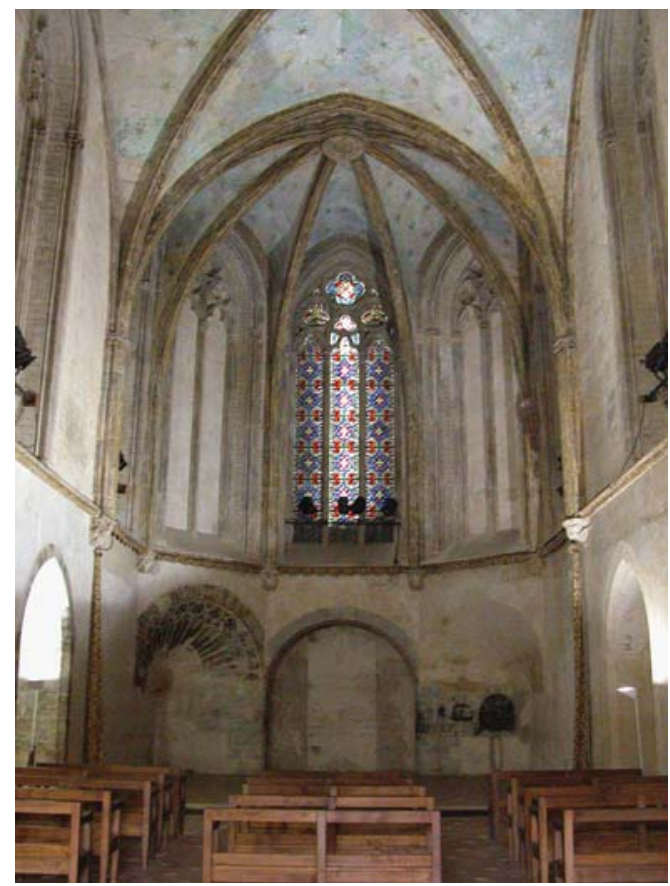

Fig. 4. Perpiñán. Palacio de los Reyes de Mallorca, interior de la capilla de la Santa Cruz.

A pesar de los condicionantes que limitaban la nueva traza de la Almudaina, las coincidencias con Perpiñán saltan a la vista. Al menos se perciben claramente en dos de los espacios fundamentales para la vida palatina: las capillas y las salas de representación. En Perpiñán, la torre central de levante, de planta rectangular, da cobijo a las capillas superpuestas de Santa Magdalena y Santa Cruz (figura 3), tal vez iniciadas antes del conflicto, pero edificadas y decoradas en buena medida a partir de 1295. El acta de dotación del capellán y los sirvientes en 1309 marca probablemente la finalización de los trabajos, al menos los arquitectónicos. Si su concepción espacial arraiga claramente en la tradición meridional, algunos de sus elementos formales y 


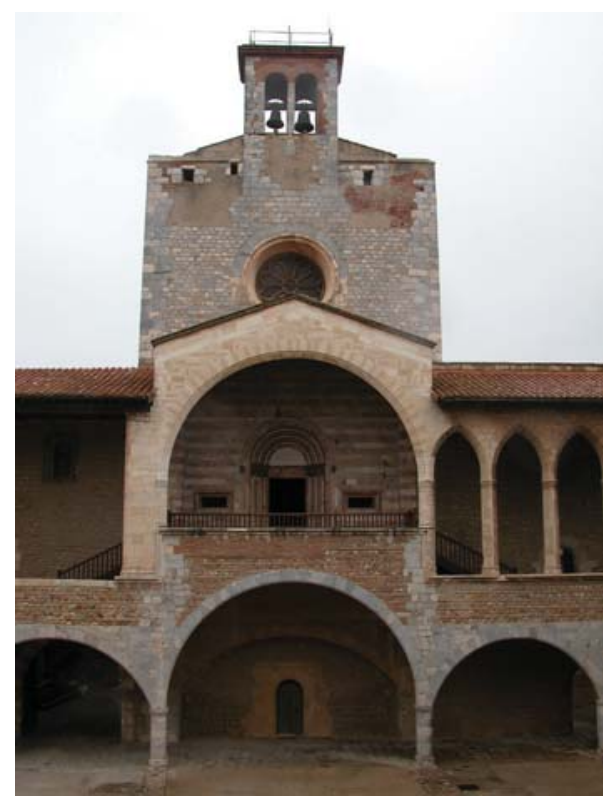

Fig. 5. Perpiñán. Palacio de los Reyes de Mallorca, exterior de las capillas superpuestas de Santa Magdalena y de la Santa Cruz.

la refinada decoración escultórica de las claves y ménsulas certifica "la intensidad de las influencias septentrionales" ${ }^{20}$. Incluso la sobreposición de las dos capillas se ha visto como reflejo de la Sainte-Chapelle de San Luis, obra que sin duda Jaime II conoció durante el tiempo que se educó en la capital francesa a mediados del s. $\mathrm{XIII}^{21}$. Edificada en los años 40 por Pierre de Montreuil, esa urna de cristal, propia de las latitudes nórdicas y expresión del poder real en la capital francesa, era difícil de replicar en un pequeño y "despedazado" reino, como era el de Mallorca. Pero no se puede descartar que hubiera la voluntad de remitir a tan singular obra, al menos en la disposición superpuesta de las dos capillas, en los dos pórticos, también sobrepuestos, que anteceden a las fachadas y en la importancia concedida al culto de las reliquias en la capilla alta, lo que originaría la apertura de ventanas a ambos lados del portal que proyectaban la visión hacia el altar, incluso cuando la capilla permanecía

20 M. DURLIAT, op. cit., 1989, p.166-168.

21 Es de suponer, como afirma J.E. MARTÍNEZ FERRANDO (op. cit., 1960, p. 46) que "tant per aquesta formació primera de la seva personalitat com per les circumstàncies ulteriors de la seva vida, la influència francesa seria en ell decisiva", puesto que el París de mediados de s. XIII ejercía "un absorbent predomini intel·lectual". Pero ignoramos cualquier aspecto esencial de dicha educación, siquiera se sabe cuánto tiempo estuvo en la capital francesa. Debió de ser antes de 1255, pues a partir de esta fecha Jaime inicia una actividad política y administrativa continuada. G. MORRO, "Jaume II, el medi familiar i l'educació", Jaume II i les Ordinacions de l'any 1300, Palma de Mallorca, 2002, p. 24. 
cerrada $^{22}$. La doble capilla se justifica aquí por razones prácticas, señaladas ya por Durliat: la inferior era la de la reina; la superior, la del rey ${ }^{23}$. Además, las respectivas dependencias reales se organizan en torno a dos patios situados a ambos lados de la torre que contiene las capillas: las habitaciones del rey al lado norte; al sur las de la reina, con acceso directo al oratorio de Santa Magdalena a través de un portal lateral (fig. 5). Esta separación de ámbitos tal vez no es a ajena a la cultura islámica, cuyo legado podía tener su incidencia, al menos en una alcazaba musulmana como era la Almudaina ${ }^{24}$. Sin embargo los rasgos técnicos y formales acuñados por las reformas arquitectónicas dejan poco margen al sincretismo cultural; beben claramente de la tradición gótica cristiana. Quizás en la decoración de las techumbres y muros de las salas se dejaría sentir el influjo del sustrato cultural islámico de Mallorca.

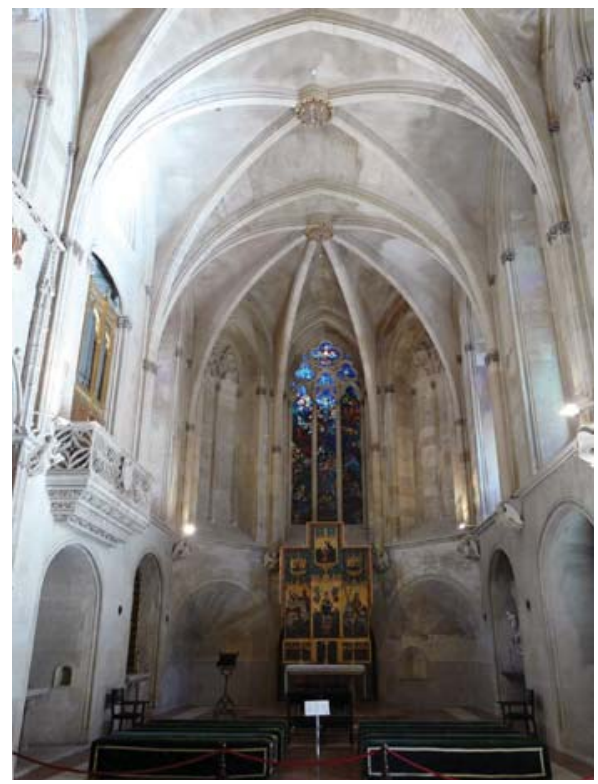

Fig. 6. Palma de Mallorca. Castillo de la Almudaina, interior de la capilla de Santa Ana.

22 Tesis desarrolladas por D. SANDRON, “Chapelles palatines: succès d'un type architectural (XIIIeXIVe s.), Un Palais dans la ville..., op. cit., en prensa. Quiero expresar mi gratitud al autor, quien me ha facilitado una copia de su artículo todavía inédito. Cabe recordar que los santuarios dobles se relacionan estrechamente con el culto a las reliquias desde tiempos pretéritos.

23 M. DURLIAT, op. cit., 1989, pp. 171-172.

24 G. Kerscher ha insistido no sólo en la importancia de este legado hispano-musulmán en los palacios del reino mallorquín, sino también en el influjo que las residencias de la Corona tuvieron en la arquitectura papal del siglo XIV; el autor subraya también la importancia del ceremonial en la disposición y ordenación de los espacios áulicos. G. KERSCHER, Architektur als Repräsentantion. Spätmittelalterliche Palastbaukunst zwischen Pracht und zeremoniellen Voraussetzungen: Avignon, Mallorca, Kirchenstaat, Tübingen-Berlín, 2000; y "Herrschaftsform und Raumordnung. Zur Rezeption der mallorquinischen und spanisch-islamischen Kunst im Mittelmeergebiet”, C. FREIGANG (ed.), La arquitectura gótica en España, Madrid-Frankfurt, 1999, pp. 251-272. Hemos conocidos sus tesis gracias al resumen en castellano facilitado con motivo de la intervención de G. Kerscher en Göttingen (febrero, 1994), recogida en la publicación de 1999. 
En la Almudaina se da también la diferenciación de las capillas. Aunque no fueran superpuestas, la reina tenía su oratorio, dedicado a San Jaime, en la planta noble, del que apenas quedan vestigios. El rey se servía del de Santa Ana, más importante por sus dimensiones, arquitectura y ubicación, pues al separar los dos patios asumió un rol en la estructuración global del castillo (fig. 6). Seguramente también destacaba por las reliquias cristológicas que poseía en tiempos de los reyes privativos. Pedro el Ceremonioso, tras la reincorporación del Reino a la Corona de Aragón, legó otras prestigiosas reliquias que, según un inventario de la capilla (1361), se exhibían con un dispositivo similar al que tenía la Sainte-Chapelle de París "tras el altar mayor, que contribuyó a la mise en valeur del tesoro sagrado de los reyes franceses" 25 .

La dirección de las obras de Perpiñán y Palma por parte del mismo maestro, el rosellonés Ponç Descoll ${ }^{26}$, explica la semejanza de ambas capillas, cubiertas íntegramente con bóvedas de crucería y con grandes trompas en los ángulos del presbiterio, sin duda uno de los rasgos más característicos. El recurso a unos mismos tipos, formas -y para los portales, incluso los mismos mármoles rojos y blancos del Rosellónobedece a un planteamiento común, el de un monarca que quiere "sentirse en casa" en las dos capitales de su reino, que multiplica las iniciativas y confía para ello en unos maestros que se desplazan al compás de las necesidades o prioridades de su Señor.

La disposición de la capilla de la Trinidad, en la catedral de Mallorca, es muy parecida a la de los oratorios palaciegos. Recordemos que se erigió por orden del mismo Jaime II, expresada en un codicilo de su testamento (1306). Sin especificar el lugar exacto, quería y mandaba que in loco decenti se construyera una capilla dedicada a la Santísima Trinidad et ibi sit spatium sufficiens ad sepulturas ubi volumus sepeliri; implicaba asimismo a su heredero universal para que la concluyera si todavía no lo estaba al fallecer ${ }^{27}$. El lugar fue en efecto "decente" y privilegiado, pues la capilla se erigió en el extremo oriental del ábside y en el eje longitudinal de una nueva catedral que, con el tiempo y a medida que los recursos financieros lo permitieran, iría reemplazando la vieja mezquita ${ }^{28}$. Esta capilla o espacio funerario, también con dos ambientes superpuestos, estaría pensada, con toda probabilidad, como panteón de la dinastía que Jaime II encabezaba ${ }^{29}$.

Las salas de representación son también espacios de particular relieve en los castillos y palacios reales; las del reino mallorquín no son ninguna excepción. Sus rasgos constructivos obedecen a un planteamiento más sencillo, y de ejecución más rápida, que los de las capillas. Son espacios de marcado eje longitudinal, con diversos tramos generados por los arcos diafragma que sostienen un envigado de madera, primando

25 F. ESPAÑOL, "Calendario litúrgico y usos áulicos en la Corona de Aragón bajomedieval: arquitectura y ornamenta", Studium Medievale, 2 (2009), pp. 195-196. La autora no descarta que algo similar se diera en la Santa Cruz de Perpiñán.

26 Sobre la importancia de este maestro en las obras reales de Jaime II, cf. M. DURLIAT, op. cit., 1989, pp. 148-149; J. DOMENGE, op. cit., en prensa.

27 M. DURLIAT, op. cit., 1989, p. 128.

28 Sobre la secuencia constructiva de la catedral, cf. J. DOMENGE, L'obra de la seu. El procés de construcció de la catedral de Mallorca en el tres-cents, Palma de Mallorca, 1997, p. 127 y ss.

29 Como observa F. ESPAÑOL (op. cit., 2001, p. 24), el malogrado fin de la dinastía impidió que la ambiciosa idea de un espacio dinástico en la cabecera de la catedral llegara a buen puerto. 
la continuidad y dilatación del ambiente, lo que les convierte en imponentes salones. La diferencia con los espacios sacros no debe ser fruto del azar, sino más bien la respuesta a una voluntad monárquica de dar mayor dignidad a las celebraciones religiosas que a los acontecimientos de carácter profano, en el contexto de una monarquía que enarbola ostensiblemente la cruz, desde que Jaime I arrebatara Mallorca a los impíos. La prioridad de destinar a lo divino lo mejor que la naturaleza brinda al hombre es una idea expresada -formulismos a parte- por Jaime III en el proemio del ordenamiento de su capilla en las Leges ${ }^{30}$.

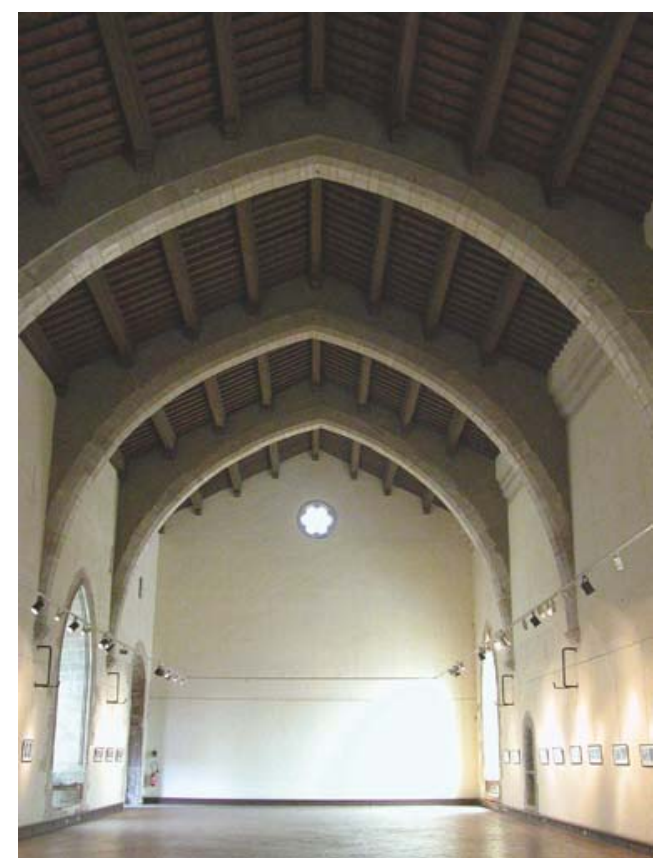

Fig. 7. Perpiñán. Palacio de los Reyes de Mallorca, Sala de Mallorca.

En el castillo de Perpiñán, la Sala de Mallorca ocupa casi toda el ala sur del patio. Su nombre no fue acuñado por el historicismo romántico, sino que aparece ya en los documentos de fines del s. XIV "aula sive sala vocata de Mallorques" ${ }^{31}$. A pesar de las restauraciones soportadas y de la desnudez con que la vemos, todavía evoca un magno espacio de representación. En Mallorca el gran salón ocupa también una parte muy importante del ala meridional del castillo, con ventanas bíforas que permiten bellas vistas al mar. Pero aquí resulta difícil imaginar el ambiente original de esta

\footnotetext{
30 “(...) ens sentim obligats a honorar Aquell qui voluntàriament s'ha dignat conferir-nos un estament d'honor. Per no esser desagraïts a tan gran benefici, li devem tributar, a la nostra presència, els serveis més honorifics que puguem". Su devoción le convence de que los ricos ornamentos (tejidos y orfebrerías) no son vanos sino necesarios. JAUME III, op. cit., 1991, vol. 1, p. 121.

31 M. DURLIAT, op. cit., 1989, p. 174.
} 


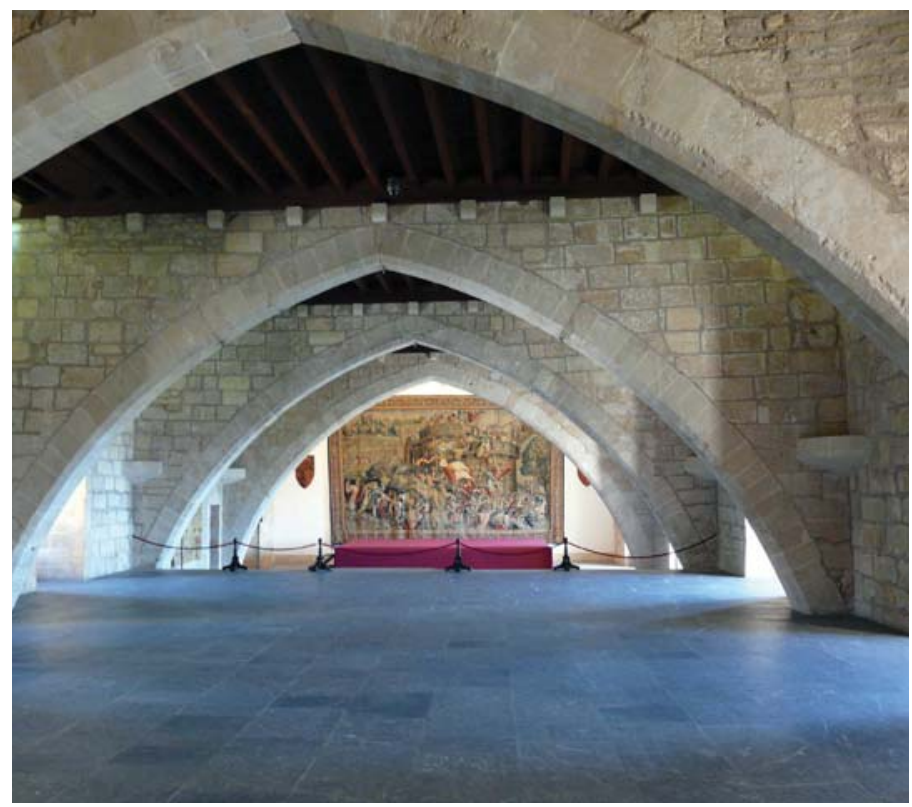

Fig. 8. Palma de Mallorca. Castillo de la Almudaina, sala mayor.

sala, alterada con la construcción de forjados que dividen su alzado en dos y la hacen mucho menos impactante. Conservamos los espacios, pero faltan todos sus arreos originales, como sucede a menudo en otras latitudes. M. Collareta afirma con todo acierto que "es preciso armarse de mucha paciencia y de un poco de imaginación para rellenar los espacios vacíos con los pertinentes objetos, sacándolos de las vitrinas de los museos y reconstruyéndolos a partir de los indicios seguros que el Medioevo nos ha legado" 32 .

Salones como los de Perpiñán y Palma van a tener sus "réplicas" en las residencias reales que se construyen con posterioridad, como la gran cambra o tinell del palacio real mayor de Barcelona, iniciada en 1359 por Guillem Carbonell. También sigue el modelo la sala major del palacio real menor, obra realizada en los años setenta. Incluso cuando el rey Martín el Humano decide, hacia 1400, construir un palacio en el Monasterio de Poblet, el maestro Arnau Bargués sigue lo que había sido la norma. Es de lógica que en realidades geográficas y políticas tan próximas como eran la Corona de Aragón y el Reino de Mallorca se siguieran los mismos tipos y técnicas constructivas, a su vez emparentados con los del Midi ${ }^{33}$. A pesar de las tensiones, desavenencias y

32 M. COLLARETA, “Arredi, suppellettili, decorazioni mobili”, E. CASTELNUOVO y G. SERGI (a cura di), Del costruire: tecniche, artisti, artigiani, committenti (Arte e Storia nel Medioevo, vol. II), Turín, 2003, pp. 317.

33 Sobre las especificidades del llamado "gótico meridional", véase: D.A., La naissance et l'essor du gothique meridional, Cahiers de Fanjeaux IX (1974); V. PAUL, "The Beginnings of Gothic Architecture in Languedoc", The Art Bulletin, LXX/1 (1988), pp. 104-122; J. DOMENGE, "Santa Maria del Mar i la 
humillaciones políticas de los soberanos aragoneses hacia sus familiares de Mallorca, las artes no reflejan esta confrontación sino que se nutren de las mismas tradiciones constructivas y se abren a idénticos influjos; en cuatro palabras -eso sí, del atinado y "visionario" Jovellanos-, la corte de Aragón sería el molde en que "fue vaciada la de Mallorca" 34 . Sin embargo, vistas las semejanzas que se dan en las salas de representación, no deja de sorprender que la capilla del palacio real mayor de Barcelona, edificada en los primeros años del s. XIV, reinando Jaime el Justo, se desmarque del tipo más septentrional de cubrición con crucerías para repetir el esquema de los salones con envigado de madera sobre arcos diafragma, excepto en el presbiterio ${ }^{35}$.

Si la tradición de estos salones parece bien arraigada en la corte catalana y mallorquina, Alfonso el Magnánimo no se va a conformar en Nápoles con un tinell o sala de ceremonias como las de sus predecesores. La mirada del rey -o de su "asesor" en materia de arquitectura- a la hora de elegir la tipología de la gran sala del Castel Nuovo se dirige a la arquitectura sacra: bien las capillas como la del palacio episcopal de Tortosa o la de los Sastres (catedral de Tarragona), bien las salas capitulares, como las de Valencia y Barcelona. A pesar de las dramáticas vicisitudes sufridas, la Sala Major o "del Triunfo" del castillo partenopeo todavía tiene poder suficiente para evocar un espacio pensado para la pompa y el ceremonial. Alfonso quiso disponer de este escenario regio para expresar su majestad y, quizás, sacralizar la legitimidad de su dinastía en un reino recientemente conquistado. La eficacia simbólica de la sala -expresión de riqueza, poder, suntuosidad- reside tanto en la misma concepción monumental del espacio como en los insistentes reclamos a la persona del rey, a través de la heráldica y de las divisas ${ }^{36}$.

\section{Usos de los paramentos textiles en palacio: ornamentar y delimitar. El testimonio de las Leges Palatinae}

Los grandes salones de Perpiñán y Palma siguen en muchos aspectos las constantes de las residencias más distinguidas de la época: se ubican en la planta noble y no en la baja -en la que se concentran las estancias funcionales, para los servicios-; están dotados de "bienes preciosos" como son los ventanales que los iluminan y ventilan; en ellos el señor administra justicia, recibe a huéspedes y a mensajeros de rango; son

historiografia del gòtic meridional", Quaderns d'Història, 8 (2003), pp. 179-200; E. MIRA, "Una arquitectura gótica mediterránea. Estilos, maneras e ideologías" Una arquitectura gótica mediterránea, Valencia, 2003, vol. I, pp. 44-57.

34 G.M. DE JOVELLANOS, Memorias histórico-artísticas de arquitectura, D. CRESPO y J. DOMENGE (eds.), Madrid, 2013, p. 155.

35 E. RIU-BARRERA et alii, La capella de Santa Àgata del Palau Reial Major de Barcelona. Història i restauracions, Barcelona, 1999; y L'art gòtic a Catalunya, Aquitectura III, Barcelona, 2003, pp. 163-171. F. ESPAÑOL (op. cit., 2009, pp. 190-193) pone en relación la capilla real con las iglesias de los grandes conventos mendicantes barceloneses y evoca la mentalidad filofranciscana que tan intensamente había calado entre los miembros de la familia real.

36 J. DOMENGE, "La gran sala de Castelnuovo. Memoria del Alphonsi regis triumphus", G.T. COLESANTI (a cura di), Le usate leggiadrie. I cortei, le cerimonie, le feste e il costume nel Mediterraneo tra il XV e XVI secolo, Montella-Nápoles, 2010, pp. 305-306. 
comedor regular del rey y se usan también para los banquetes oficiales. Además, con los arreos se acentúa todavía más el carácter de espacio público, ceremonial. Dado que las funciones son diversas, el mobiliario ha de ser movible -como indica la propia etimología del término- y la escena tiene que ser fácilmente liberada para nuevas exigencias. Todavía habrá que esperar tiempo para llegar al concepto moderno de decoración doméstica estable, por decirlo de algún modo ${ }^{37}$.

Sin duda la decoración textil asume una clara prevalencia. Pero la pérdida de los paños obliga a recurrir a fuentes figurativas, literarias y documentales para atestiguar "il ruolo preeminente svolto dai tessuti pregiati negli interni trecenteschi" ${ }^{38}$. Las dependencias de los castillos y palacios medievales se revistieron con paños ricos, no sólo por razones de ornato sino también de confort. La alfombras cubrían el pavimento y la decoración mural solía confiarse a tejidos y tapices - costosos y frágiles a la vez- con un repertorio decorativo en buena medida estandarizado: emblemas heráldicos, motivos geométricos, cacerías, imágenes religiosas, "historias" y decoraciones vegetales. Los principales muebles se guarnecían también con ricas estofas; así los bancales ${ }^{39}$ disimulaban los escaños, y los baldaquines de ricas telas resaltaban la dignidad de los de mayor rango.

Entre los ornamentos de carácter textil merece la pena destacar el valor y la utilidad de los tapices y cortinajes, pues no se limitan tan solo a enriquecer y connotar el espacio, sino que lo pueden "modelar", definir y transformar profundamente. Se supone que grandes salones como los que tratamos eran de gran versatilidad porque podían ser adaptados a funciones diversas mediante los paramentos textiles. En este sentido, el códice de las Leges Palatinae antes evocado brinda un valioso testimonio coetáneo sobre la costumbre y los significados del uso de los paños en varios contextos y ocasiones de la vida en la corte. En una de las ordenanzas referidas a los camareros, escrita bajo el epígrafe "De las vestiduras y otros ornamentos" ${ }^{40}$, Jaime III dicta un sinfín de normas para que sus sirvientes dispongan de los paños adecuados para cada circunstancia y los instalen según el agrado del rey. Aunque "del dicho al hecho hay un gran trecho" es de suponer que las Leyes, ni que sea idealmente, reflejan hábitos cortesanos de moda y que en los palacios de los soberanos mallorquines esas prácticas se seguían, aunque fuera con menos protocolo y rigor que los exigidos por Jaime III en el texto. Por lo pronto, no deja de sorprender la consigna general: observar la honestidad y sobriedad en todos los ornamentos. Teóricamente pues aboga por la mesura, no para ahorrar gastos, aclara, sino para dar buen ejemplo de honestidad y moderación, evitar la altivez y lo superfluo. La riqueza excesiva en los vestidos, añade, induce más a la fastuosidad que a la verdadera gloria.

Después de regular con toda minucia los paramentos de los lechos reales, de los de los camareros que duermen junto a él, y de los que se llevan en los viajes, expresa la

37 Fija una serie de conceptos clave aquí retomados: M. COLLARETA, op. cit., 2003, p. 317.

38 M. TOMASI, "L'arredo della casa", M. SEIDEL (a cura di), Storia delle arti in Toscana. Il Trecento, Florencia, 2004, p. 254.

39 Son los tapetes o cubiertas que se ponen sobre los bancos para adorno o para cubrir su madera.

40 JAUME III, op. cit., 1991, pp. 111-112 (en la traducción al catalán de M. Pont); pp. 168-169, en la transcripción latina de Ll. Pérez. Todos los comentarios que siguen parten de esta ordenanza. 
orden de disponer siempre de abundantes cortinas de lino verde y rojo, de longitud suficiente para poner ante la cama, cuando se tercie. Pero se prevé otro uso para estas cortinas: tienen que servir ad mediandum sive per medium dividendum una cameram vel aliam magnam domum vel [ad] usos alios similes, o sea, para partir o dimidiar una estancia o sala grande, como si de tabiques se tratara. Estamos ante una clara evidencia de la importancia de los paramentos textiles para compartimentar los grandes espacios o salas de ceremonias, que podían resultar funcionales para las grandes ocasiones, pero poco prácticas para actividades de menor concurrencia o con una dimensión más privada e íntima. La "obsesión" del rey por el color le lleva a ordenar que dichas cortinas siempre deban combinarse cromáticamente con los cubrecamas $\mathrm{y}$ cielos ${ }^{41}$.

Otras doce cortinas, con los mismos colores -y a juego con las vestimentas de los lectores- servirán para preparar los oratorios reales siempre que el soberano quiera oír el divino oficio. Una ordenanza como ésta tiene todo su sentido en una corte itinerante, pues en Perpiñán y en Palma las capillas reales, aparejadas con el debido mobiliario y ataviadas con los paños requeridos, evitarían instalaciones tan efímeras como las que el rey propone, aunque pudieran reservarse para celebraciones especiales. El oratorio cotidiano, "construido" con las cortinas, se usaría de manera más rutinaria en los viajes o al estar fuera de los palacios con capilla "estable". Aunque avancemos en el tiempo, algunas bellas miniaturas pintadas en los libros del gran bibliófilo, el duque Berry, muestran con claridad que con unos cortinajes se podía "improvisar", en cualquier lugar y momento, un oratorio o capilla para las prácticas de devoción de los príncipes ${ }^{42}$.

El acopio de textiles no se limita solamente a los referenciados; otras indicaciones precisas del texto revelan hasta qué punto fueron elementos clave de la escenografía real. Jaime III quería tener a disposición ocho paños de lana -más delicados que las alfombras que cubren el pavimento, junto a la cama, se dice- y dieciséis cojines a juego, también de lana: ocho de forma alargada y otros tantos cuadrados. Et serviant dicti panni et cossini tam in oratorio nostro tenendo quam etiam in consilio eos ponendo retro nos in parietibus extentos et affixos. Los mimos paños servirían indistintamente para configurar un oratorio cuando fuera menester o para dignificar las reuniones del consejo real; en este caso penderían de los muros detrás del rey, a manera de cortinajes de ceremonia.

41 Los colores son objeto de una especial atención; el verde es el color de los paramentos que se usan desde Pascua a Todos los Santos, o sea, a lo largo de la primavera, verano y comienzos de otoño; el rojo es el color invernal, utilizado el resto del año. Se trata de una periodización genérica en la esfera cultural de la época, pues también los hábitos corales de los canónigos se mudaban por estas mismas fechas. Por ejemplo, en 1322 el obispo de Mallorca Guiu Terrena ordenaba que canónigos, domeros, beneficiados y clérigos en general vistieran capas negras y sobrepelliz durante los oficios divinos, desde las vísperas de la Vigilia de Todos los Santos hasta las de la Vigilia de Pascua. J. VICH y J. MUNTANER, Documenta Regni Maioricarum (Miscelanea), Palma de Mallorca, 1945, pp. 138. En la elección del color por parte del rey deben de pesar tanto razones prácticas de accesibilidad al mercado de los paños, como intenciones simbólicas que, lamentablemente, no se hacen explícitas en la ordenanza.

42 Por ejemplo en sus Petites Heures, Juan de Berry aparece en plegaria ante la Virgen (f. 122) y en unos Evangelios conservados en Bourges, se muestra orando ante Andrés, uno de sus santos predilectos (f. 181). Véanse las imágenes en: Paris·1400, París, 2004, p. 325; Dossier de l'art, 107 (2004), p. 51. 


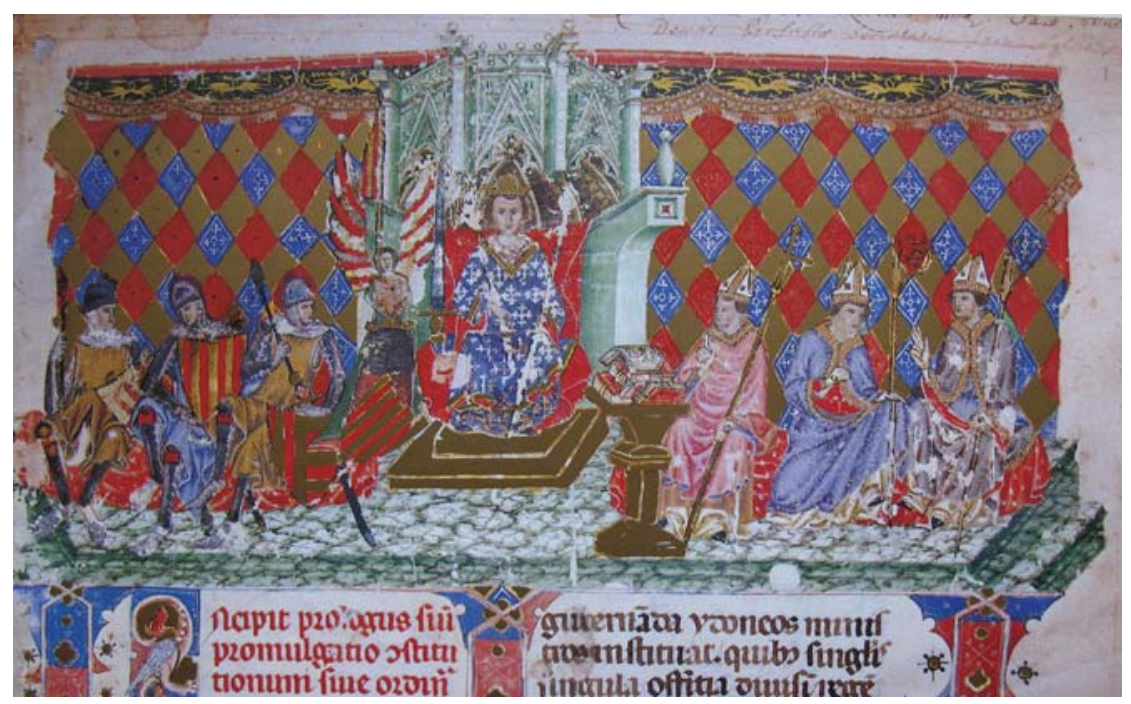

Fig. 9. Bruselas (Bibliothèque Royale, ms. 9169). Leges Palatinae (1337), Jaime III y el consejo real (f. 1).

Las ilustraciones del consejo real en la Leges acreditan que las disposiciones reales tenían su aplicación, o bien que se inspiraban en prácticas del todo arraigadas. Tanto en el folio 1 como en el 56v. el rey se presenta con toda su majestad, acompañado por los brazos militar y eclesiástico del reino. En la primera escena (fig. 9) aparece realzado en un trono arquitectónico de formas góticas, eso sí, con el asiento recubierto por un tejido rojo, mientras en la segunda, más discretamente ataviado, su silla se camufla bajo los paños marrón y rojo que recubren respectivamente el asiento y el respaldo (fig. 10). También la disposición y magnificencia de las estofas que sirven de fondo a las escenas son distintas: en el primer caso una auténtica cortina de losanges rojos, azules y dorados pende de una barra cilíndrica y da una particular suntuosidad al ambiente; en la segunda representación un paño rojo, sembrado de pequeñas flores blancas, se extiende en la parte superior y se anuda "artificialmente" en los dos pináculos que flanquean la escena, como si de un decorado teatral se tratara. Un paño con el mismo color y estampado sirve de bancal en la primera de las dos miniaturas, mientras en la segunda los bancales son un simple paño marrón, a juego con el del sitial del rey.

Jaime III deseaba también panni linei magni et historiati, unos menos lujosos y más pequeños que los restantes, pero igualmente historiados. Se utilizarían para colgar de la pared, detrás de él, cuando se sentaba a la mesa o para poner en la cabecera de la cama cuando se hallaba en un lugar donde el lecho no estuviera guarnecido con su superposito paramento, refiriéndose seguramente al dosel o cielo de la cama. Es muy probable que los paños con representaciones figurativas que el rey anhelaba fueran tapices. Las iniciales decoradas que encabezan las ordenanzas de los scutelliferis 


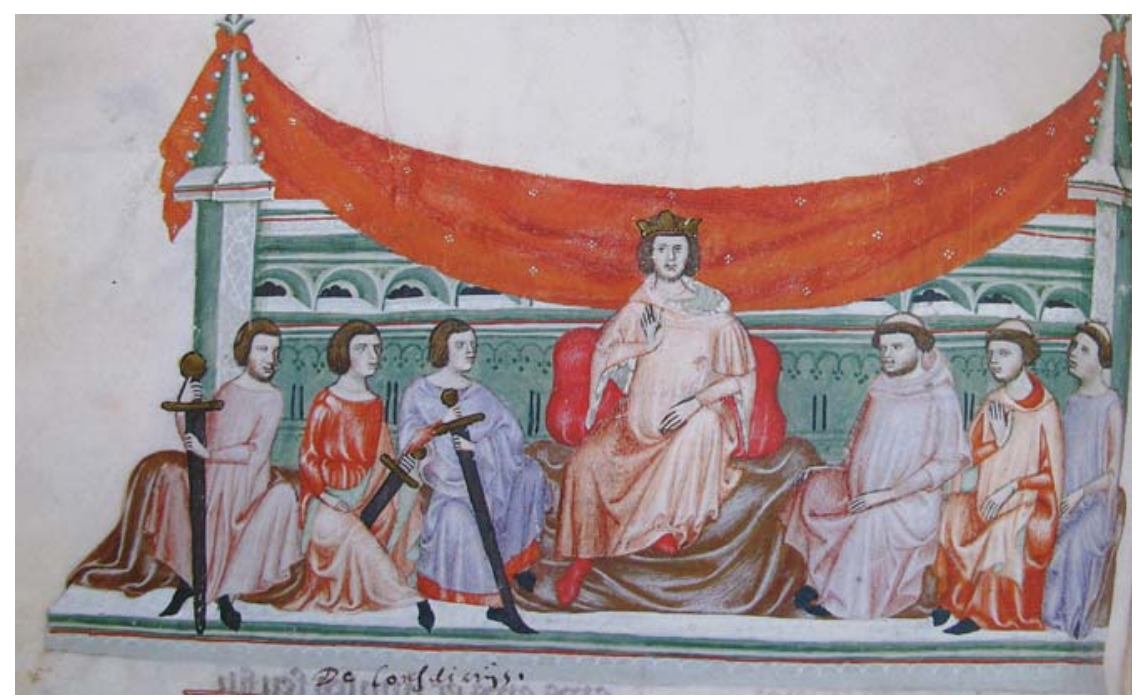

Fig. 10. Bruselas (Bibliothèque Royale, ms. 9169). Leges Palatinae (1337), Jaime III y el consejo real (f. 56v.).

regiis o portadores de la vajilla real (f. 10v.) y del paratore et eius coadiutore (f. 33v.) ${ }^{43}$, aunque sean representaciones sin demasiado detalle, por lo reducido de su formato, documentan visualmente esas prácticas. El comienzo de esta última ordenanza resulta también elocuente, pues el rey expresa la conveniencia de que su cámara esté debidamente ornamentada, no con decoraciones superfluas, sino adecuadas a la expresión de honestidad que requiere su estamento y siguiendo la moderación de las costumbres. Para los pormenores de la colocación de los paramentos remite sin embargo a la ordenanza general que nos ocupa. Todavía matiza que los tapices más valiosos, aquellos que resaltan por su belleza, se usarán en los días más solemnes, como lo exige su prestigio, no para disminuir la solemnidad, sino para magnificarla. Se trata de un matiz importante, con el que se quiere resaltar la voluntad de no hacer del fasto algo gratuito.

El listado de ornamentos textiles sigue con los ocho bancales de lana, bien obrados y de diversos colores, que el rey pide para cubrir el escaño en el que se sienta a comer; igualmente tiene que haber dos cojines alargados de terciopelo del color de les armas reales, o sea, amarillo y rojo. Finalmente, para sus actos públicos exige dos doseles (retrodorsaria, es el término utilizado), dos bancales, dos cojines largos y cuatro cuadrados de panno aureo eiusdem coloris. Servirán, dice textualmente, para cuando "por alguna causa debamos de hablar a nuestro pueblo y lo convoquemos a nuestra presencia". Otras indicaciones, tal vez más sumarias, acaban por mostrar el esmero que puso el rey en regular estos ornamentos: quería disponer de cubrecamas forrados

43 Eran los encargados de los paramentos y cortinas de la cama real, así como de los que se usaban para cubrir las sillas del consejo y del comedor. 
de diversas pieles, de vannae, linteamina, coopertoria et aliae decentes vestes para aparejar tres o cuatro camas, en caso de necesidad. Delegaba a los camarlengos la responsabilidad de que todas las vestiduras y ornamentos fueran renovados cuando se estimara oportuno y de tenerlos siempre preparados en cantidad suficiente para los actos que los requerían. La exigencia real acaba por imponer que no se tenga un solo paramento para cada celebración, sino varios y de cada uno de los colores ordenados. La razón de esta abundancia se aclara luego: cuando el rey quiera disponer de los paños para unos actos que se llevan a cabo en distintos lugares, la ordenanza no puede dejar de cumplirse por carencia de ornamentos obrados con los materiales, formas y colores requeridos ${ }^{44}$.

Queda suficientemente claro, pues, el valor otorgado a semejantes decoraciones y lo que se pretende con ellas: magnificar al soberano, darle un particular relieve, enmarcarlo en una especie de aura de solemnidad cuando aparece ante sus iguales y sus subordinados; en definitiva, crear escenarios pensados para la exaltación de la majestad regia y con la pompa que el ceremonial exige. Todo parece reglamentado, controlado, formalizado, de acuerdo con una etiqueta cortesana perfectamente estudiada, tal vez porque ayuda a crear una imagen del poder, más todavía cuando éste se pone en entredicho, como lo fue el de la Corona mallorquina. Pero las Leges son eso: leyes, normas. No sabemos si se siguieron ni cómo se aplicaron en realidad; la manera en la que han llegado las salas de los palacios y la falta de referencias documentales que nos descubran su aspecto cuando eran utilizadas por los soberanos demanda prudencia.

Tampoco los espacios pintados por los artífices que se encargaron de ilustrar las Leyes alcanzan a adentrarnos en los auténticos ambientes áulicos en que se desarrolló la vida de los soberanos mallorquines. Por varias viñetas desfilan los oficiales de la corte, inmersos en sus funciones; esos retales de vida palaciega se enmarcan en arquitecturas de tono verdoso, articuladas a partir de sucesivas arcadas y vanos de medio punto, techos planos y cúpulas de casetones, frontones triangulares y algún pináculo, casi el único elemento que entronca con la arquitectura gótica de la época. Para nada se inspiran en los verdaderos espacios en los que latió la vida palatina. Más bien son el resultado del impacto de los modelos utilizados por el taller que se encargó de pintarlas; modelos enraizados en la cultura figurativa italianizante, que desde las primeras décadas del Trecento nutre la pintura del Rosellón. Las arquitecturas de nuestro códice remiten a las de los grandes maestros italianos, pero en las pinturas murales de Giotto en Asís o en los mosaicos de Santa María in Trastevere de Pietro Cavallini en Roma, las cúpulas y techos con casetones, así como la arquitectura en general, están resueltos con un conocimiento más maduro de la representación espacial. El ilustrador de las Leges pinta de manera más insegura, menos coherente, brindándo-

44 “(...) taliter quod quando continget Nos pro uno actu in diversis locis paramenta praeparare, ex carentia praedictorum, ordinatio nostra praesens, neque in modo neque in coloribus, valeat praetergredi quoquomodo". 
nos fantasiosos edificios como los que simultáneamente se ven en las obras de otros italianos que trabajaron a la sombra de los grandes maestros ${ }^{45}$.

Desde que M. Meiss ${ }^{46}$ diera nombre y obra al "Maestro de los Privilegios", las Leges se han considerado una creación surgida en el entorno de este taller activo en Mallorca entre 1325 y 1345, aproximadamente, en el que se pintaron tablas e ilustraron manuscritos. Sus referentes figurativos más explícitos se hallan en la obra de los secuaces de Duccio, bien el pisano Maestro di San Torpè, bien el sienés Memmo di Filippuccio. Puesto que un artífice llamado Joan Loert, documentado en Mallorca durante el segundo cuarto del siglo XIV, se revela como una personalidad destacada en el mercado pictórico de Palma, se ha propuesto que pudiera tratarse del ignoto Maestro de los Privilegios ${ }^{47}$. La cantidad de encargos que recibe el taller y sus contactos con otros artífices adquiere todavía más sentido si se considera la estrecha relación familiar y profesional de Loert con Arnau Boas, pintor documentado primero en Perpiñán $\mathrm{y}$, a finales de los años 30, en Mallorca. Arnau casó con la hija de Loert, se encargó de la formación pictórica de su cuñado y se asoció con su suegro, cancelando la sociedad de officis pictorie en $1340^{48}$. Las raíces rosellonesas del taller -no es descartable que tanto Loert como Boas procedieran de allí, al igual que otros tantos maestros al servicio de la corte- podrían pues ser definitivas para entender la recepción, adaptación y difusión de las experiencias italianas en el ámbito de la Corona.

\section{El castillo de Bellver: originalidad tipológica ¿con valor simbólico?}

Entre las construcciones de la realeza mallorquina sobresale sin duda el castillo de Bellver, la más genuina e insólita de cuantas se realizaron. Intenciones simbólicas y tal vez influjos ideológicos de los asesores reales marcan el proyecto inicial de esta joya arquitectónica, cuyo interés rebasa los límites de la Corona; es sin duda una construcción emblemática en el panorama de la arquitectura militar y residencial de la Baja Edad Media. Aunque obviemos la descripción y filiación de los elementos que configuran el castillo, merece la pena recordar algunas coincidencias y divergencias

45 Lo pone de manifiesto una tabla poco conocida de un anónimo toscano de comienzos del Trecento; la escena de la Anunciación halla cobijo en una arquitectura que creo comparable a las de nuestro taller, aunque el estilo de las figuras sea muy distinto. T. KUSTODIEVA, "Un'icona sconosciuta dalla collezione Lichaciov", Paragone, 47-48 (1994), fig. 10.

46 En realidad, la perspicaz mirada de Meiss distinguía entre el maestro, el taller, un seguidor y un close follower of Master of the Privilegios, a quien asigna el códice que nos incumbe. M. MEISS, "Italian style in Catalonia and a fourtheenth century Catalan workshop", The Journal of The Walters Art Gallery, IV (1941), pp. 51-54. Tratamos más ampliamente de la cultura figurativa del Maestro de los Privilegios en: J. DOMENGE, "The 'Leges Palatinae"”, JAMES III, Leges Palatinae, Palma de Mallorca, 1994, pp. 20-26.

47 M. DURLIAT, op. cit., 1989, pp. 273-279.

48 Aporta abundantes documentos sobre ambos maestros, G. LLOMPART, Miscelánea documental de pintura y picapedrería medieval mallorquina, Palma de Mallorca, 1999, pp. 24-30. En muchos instrumentos notariales que conciernen a Loert, aparece un Romeus Manresa como testimonio que, con toda probabilidad, es el Romeus des Poal que copió el Libro de los Privilegios. Esta proximidad podría ser fruto de una colaboración profesional. G. LLOMPART e I. ESCANDELL, "Estudi historicoartístic", R. URGELL (dir.), Llibre dels reis. Llibre de franqueses y privilegis del regne de Mallorca, Palma de Mallorca, 2010, pp. 116-118. 




Fig. 11. Palma de Mallorca. Castillo de Bellver, alzado y sección (ilustración que acompaña una de las Memorias escritas por G.M. de Jovellanos).

con las restantes edificaciones tratadas ${ }^{49}$. Bellver se erigió como construcción de nueva planta, con una traza regular y diáfana, sin estar condicionada por preexistencias. Una sabia planificación, sumada a un proceso de construcción rápido, confirió gran unidad al castillo. La robustez de su exterior -dado el carácter defensivo- se compensa con un interior abierto, placentero para la vida señorial, constituido por dos galerías superpuestas. La inferior, cubierta de madera, se abre al patio central mediante una galería con pilares cuadrangulares y arcos de medio punto; la superior se cubre con crucerías y tiene un trazado más complejo, elegante y funcional -desde el punto de vista constructivo- que el de los restantes castillos, aunque coincide con ellos en los módulos compositivos ${ }^{50}$.

El rasgo que otorga mayor originalidad a Bellver, a saber, su estructura perfectamente circular, es el que más dificultades de interpretación conlleva. El porqué de tal forma, los supuestos referentes o modelos, el grado de implicación del rey en la elección de la traza y el probable simbolismo implícito, son aspectos que todavía continúan abiertos.

El rigor formal de todo el conjunto salta a la vista y se ha interpretado como muestra de la evolución técnica que, desde la segunda mitad del s. XII, conduce a formas arquitectónicas más estructuradas, regulares y geométricas. Éstas se concretan en

49 Algunos aspectos se tratan con mayor detenimiento en: J. DOMENGE, op. cit., en prensa.

50 La combinación de los arcos de Bellver repite el esquema de la galería meridional de la Almudaina y del ala de poniente de Perpiñán: a cada arcada (de medio punto) del piso inferior le corresponden dos en el superior, resueltas con arcos ojivales. 


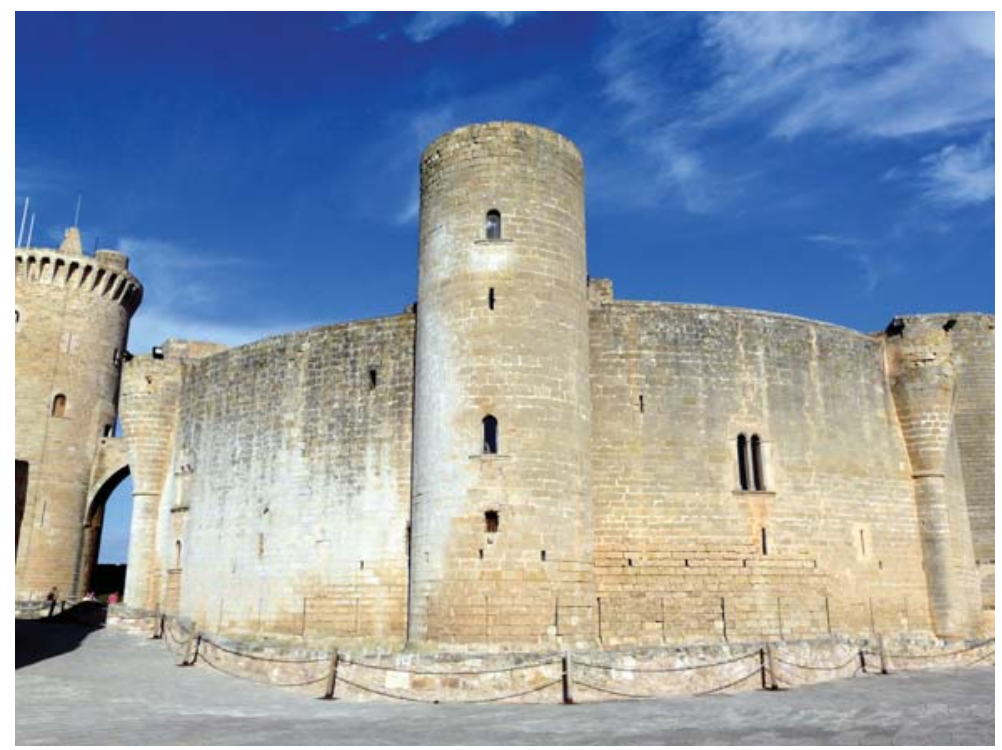

Fig. 12. Palma de Mallorca. Castillo de Bellver, exterior con las torres y atalayas.

plantas triangulares, cuadradas, poligonales o, como en Bellver, circulares, el punto final o meta de esta evolución ${ }^{51}$. Precisamente este rasgo, el ser una obra toda ella circular, exige una compleja estereotomía. El rosellonés Ponç Descoll, maestro documentado al frente de las obras reales a fines del s. XIII y comienzos del XIV, pudo ser el responsable de la traza, dada su más que probable maestría en trabajar superficies curvas, como atestiguan los documentos que le vinculan a varias obras actualmente desparecidas. Su posible identificación con el Magister Poncius documentado en la catedral de Albí hacia 1293-1295 hace todavía más creíble la hipótesis, pues allí muestra ya el conocimiento de las trazas basadas en el círculos y sus segmentos y la capacidad para resolver volúmenes cilíndricos que dan una peculiar imagen al exterior de la catedral ${ }^{52}$. Su destreza se pone aún de mayor relieve al pasar del ladrillo utilizado en Albí a la piedra de cantería en Bellver, por las exigencias de estereotomía que ello requiere. La plasticidad mural, basada precisamente en el juego de esos volúmenes cilíndricos, se repite en ambas obras, y debía manifestarse también en las restantes construcciones documentadas de Ponç Descoll, como las murallas de Perpiñán y Ciutadella (Menorca), también dotadas de torres cilíndricas.

\footnotetext{
51 En palabras de J. Mesqui, se trata de "un des plus extraordinaires symboles de cette perfection de plan ... un cas rarissime dans la fortification occidentale”. J. MESQUI, Les châteaux forts. De la guerre à la paix, París, 2008, pp. 41, 44.

52 M. DURLIAT, "Les châteaux des rois de Majorque: origine de leurs partis architecturaux", Botlleti de la Societat Arqueològica Lul·liana, 41 (1985), pp. 55-56.
} 
En lo que concierne a la tipología se tiende a recordar la forma circular de los castillos de Restormel (en el condado de Cornwall), de Gisors, en Normandía, y de Beynes, en Île-de-France, construidos hacia 1100, aunque luego se transformaran y se conozcan tan solo sus ruinas. Sin embargo ignoramos los vínculos históricos y los enlaces artísticos que permitirían verlos como antecedentes de la forma circular adoptada en Bellver. Las fortificaciones del mezzogiorno italiano, construidas a partir de 1240 por Federico II Hohenstaufen, también han centrado la mirada de quienes han buscado los antecedentes bellvéricos. En este caso, cronología, política y cultura juegan a nuestro favor, pues el dominio catalán del reino de Sicilia y el entronque de la casa mallorquina con los Anjou de Nápoles en los primeros años del siglo XIV -a través del matrimonio de los infantes Sancho y Sancha de Mallorca con María y Roberto de Anjou- pudieron tener sus repercusiones culturales. Entre las construcciones de Federico, Castel del Monte es la que conceptualmente más se acerca a Bellver. Comparten la planta centralizada, la disposición anular en torno a un patio, la pureza geométrica, el alzado de dos niveles, etc., pero las diferencias son evidentes: la planta es octogonal y los ángulos aparecen reforzados con torres, también octogonales; carece además de la galería interior que otorga un carácter tan apacible al castillo de Bellver. Tal vez su semejanza resida más en las intenciones de sus respectivos promotores y su opción por formas singulares que en los paralelismos de estructura y forma. Federico lideró un plan defensivo de alcance imperial que pretendía no sólo el dominio real y efectivo sobre el territorio, sino también una presencia simbólica con gran carga ideológica. Sus castillos muestran la búsqueda de soluciones espaciales articuladas que, por la simetría, geometría y regularidad de los conjuntos, se asemeja a lo que luego se ve en Bellver. Los maestros que trabajaron para Federico, además de atender a los requisitos defensivos de los castillos, también respondieron a la búsqueda de dignidad y belleza arquitectónica para satisfacer los anhelos imperiales de unas residencias adaptadas a las necesidades representativas ${ }^{53}$.

En cualquier caso, la originalidad del maestro que concibió el castillo de Palma está fuera de duda. Una traza a la vez tan difícil y genuina no puede explicarse convincentemente por simples razones de funcionalidad; los usos del castillo como fortaleza y residencia podían resolverse con morfologías más comunes y simples que evitaran los espacios torcidos - como los son todos los del castillo- y que no resultan precisamente funcionales. No sorprenderá pues que la circularidad que domina el todo y las partes del castillo se haya relacionado con la búsqueda de perfección, tal como es expresada por un pensador de capital importancia y próximo al soberano Jaime II, Ramon Llull. El elogio que él hace de la forma circular (fuente de movimiento y órbita celeste) pudo de algún modo pesar en las exigencias del monarca a su constructor. Si para Llull una buena arquitectura humana era la que más se acercaba a la imagen divina, tenía su sentido optar por el círculo, o sea, la forma de la perfección.

53 L. SANTORO, "I castelli di Federico II: funzioni e messaggi”, B. ULIANICH y G. VITOLO (a cura di), Castelli e cinte murarie nell'età di Federico II, s.1., 2001, pp. 58, 63. 


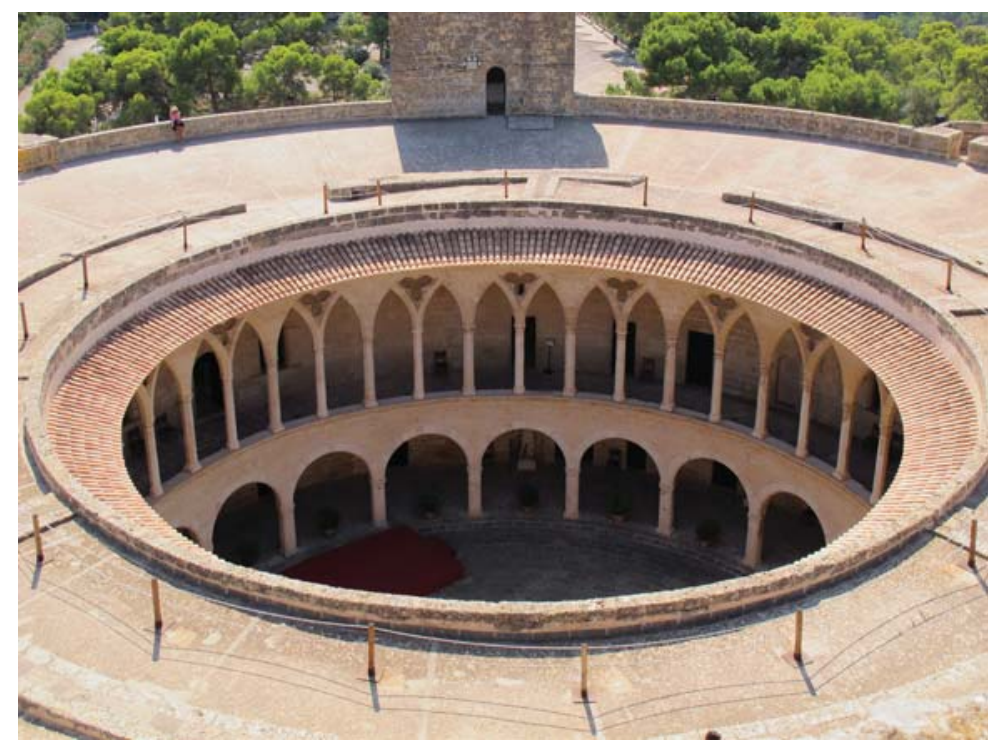

Fig. 13. Palma de Mallorca. Castillo de Bellver, patio circular desde la torre del homenaje.

El arquitecto dio a la piedra la "forma de la eternidad, del movimiento sin principio ni fin", o sea la forma capaz de realizar lo que Llull llamaba "el gran edificio" 54 .

Sin embargo ningún documento aclara las intenciones o propósitos de Jaime II al mandar la construcción de un castillo circular. Como promotor pudo ejercer un influjo considerable sobre la obra, pero es difícil pensar que actuara con toda libertad en su elección. Queriéndolo o no, siguió las tendencias y hábitos artísticos de su época y tuvo que someterse a los conocimientos arquitectónicos -en particular de estereotomía- de quienes debían de dar forma tangible a su idea ${ }^{55}$.

Sea como fuere Bellver es, a mi entender, la obra arquitectónica que mejor refleja el afán de Jaime II por una arquitectura áulica que pone la originalidad y novedad al servicio de la autoafirmación política. Y las Leges Palatinae de 1337 son como el canto de cisne de una realeza que quiere mostrarse con toda dignidad y solemnidad, tal vez para reclamar, con la legitimidad que le arropa, una merecida consideración, aunque sea con estos recursos simbólicos.

54 A. CIRICI, Arquitectura gótica catalana, Barcelona, 1968, pp. 262-263. Otros valores simbólicos se han asociado a la planimetría del castillo de modo que se ha visto Bellver como "una parábola moral al estilo de Llull”. J. GAYÀ, "Simbologia de Bellver", P. MARIMON, El descobriment d'un símbol. Guía temàtica del castell de Bellver, Palma de Mallorca, 2011, pp. 11-13.

55 El razonamiento parte de una observación general de B. Brenk: "Il committente può talora esercitare un considerevole influsso su contenuto e forma dell'opera d'arte, ma non è mai del tutto libero nelle sue suelte, giacché spesso, volente o nolente, si sottomette alle tendenze e alle mode artistiche di un'epoca o di un centro artistico, e solo assai di rado accace che un committente inauguri un proprio mondo di forme e contenuti". B. BRENK, "Comittenza e retorica”, E. CASTELNUOVO y G. SERGI (a cura di), op. cit., 2003, p. 4. 


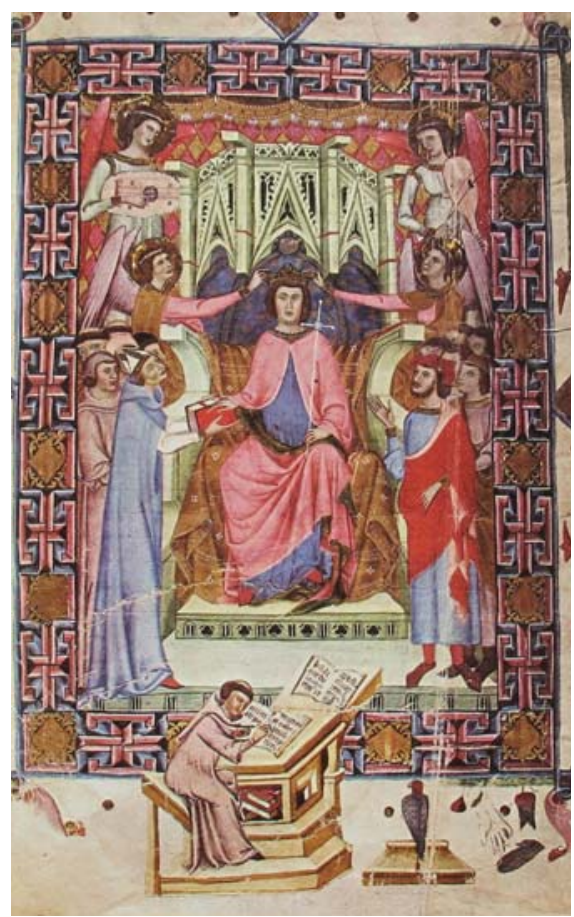

Fig. 14. Palma de Mallorca (Arxiu del Regne de Mallorca, cod. 1). Llibre dels Privilegis (1334), Jaime I, creador del reino (f. 13v.).

\section{Manifiestos políticos en imágenes}

Los jurados de Mallorca parecen transitar caminos similares cuando tres años antes, en 1334, encargan la compilación de privilegios y franquicias otorgados por los monarcas a los ciudadanos del reino en un lujoso códice de pergamino con ilustraciones en las que abundan las efigies reales ${ }^{56}$; un reino que, como recuerdan quien o quienes dirigen la iconografía del códice, fue creado por el Conquistador al liberarlo de los enemigos, o sea, los musulmanes. La única inscripción que Romeu des Poal, escribano del libro, incluye en el frontispicio (f. 13v.), "retratándose" precisamente en el acto de redactarla, reza: Benedicat Dominus regem Jacobum illustrem qui eripuit regnum

56 Cabe recordar que tanto este códice como el de las Leges se realizan en una década difícil, no sólo por la crisis agraria y las penurias económicas, sino también por los grandes problemas en la convivencia política de los estados europeos. Sobre las tensas relaciones de poder entre la monarquía y la Juraderia de Mallorca, cf. P. CATEURA, op. cit., 1998, pp. 9 y 136. Urgía, además, reunir en un códice las disposiciones vigentes, eliminando las que habían sido derogadas o las que eran contrarias a los intereses de la Universidad; se imponía asimismo seleccionar los materiales normativos de acuerdo con un criterio preciso. El resultado fue este lujoso códice reservado a determinadas solemnidades como los actos de juramento de los oficiales de la Universidad, virreyes y otros cargos reales. Cf. A. PLANAS, "Estudi historicojurídic", R. URGELL (dir.), op. cit., 2010, pp. 54-55, 71. 
ab inimicis (fig. 14). A mi entender no se ha dado la importancia debida a esta sentencia que, además de disipar la duda sobre la identidad del "retratado", el Conquistador, aporta claves interpretativas sobre el sentido de la representación: se alaba y enaltece al creador del Reino. Habida cuenta, además, de que fueron los jurados quienes encargaron esta compilación, la imagen puede leerse "en clave de autoafirmación del propio organismo de los Jurats" ${ }^{57}$. El origen, la razón de su existencia como institución residía en la voluntad de Jaime I y era oportuno recordarlo -con los medios al alcance: en este caso con un mensaje en imágenes- en momentos delicados, como lo fue la década de 1330, cuando los magistrados veían cómo sus privilegios se ponían en entredicho. La imagen se convertía pues en una suerte de exhortación a que el pacto sellado entre el primer rey y los Jurados fuese respetado por el soberano reinante.

Así, la creación del Reino por parte de Jaime I creo que justifica el tipo de representación que se le tributa: dos miniaturas a toda página, encabezando los privilegios concedidos por el monarca, tanto en la parte latina como en la traducción catalana ${ }^{58}$. En la primera se le representa de modo mayestático, sentado en rico trono, con dosel de arquitectura gótica, sillón cubierto de paños y cortinaje de fondo, como quería manifestarse públicamente su nieto Jaime III, según el testimonio de las Leges. Mientras con la derecha concede los privilegios, su mano izquierda empuña una gran cruz a modo de cetro, atributo que la aludida inscripción validaría, pues bajo el signo de la cruz venció a "los enemigos" (Nós anam en est viatge en fe de Déu, proclama en su crónica ${ }^{59}$. Otro detalle de la representación resulta todavía más sorprendente: Jaime I es coronado por sendos ángeles que flanquean el trono, lo que contribuye no sólo a sacralizar al monarca cristianísimo que "liberó" el reino, sino a preservar la legitimidad de una Corona tocada por la gracia divina. ${ }^{60}$ Bien es cierto que Jaime I no fue coronado - como se ha esgrimido para relativizar la identidad del "retratado" ${ }^{1}$-, pero a mi entender se trata más bien de una coronación simbólica, que no histórica, con la que se pretende reafirmar la legitimidad de la Corona de Mallorca y la vigencia de los privilegios que su creación supuso para los habitantes del Reino. Es oportuno

57 “No habría que ver entonces aquí a don Jaime, como fundador, por la gracia de Dios, del nuevo reino cristiano insular, en el instante de otorgar los privilegios que instituían a los propios Jurats?", se pregunta M. Serrano. Creo que la respuesta es afirmativa. M. SERRANO, "Falsas historias, proposiciones certeras. Dominio visual e imágenes persuasivas en el entorno áulico de la Corona de Aragón”, Codex Aquilarensis, 27 (2011), pp. 203-204. La impronta de la iconografía monetaria y numismática mallorquina en la aragonesa, así como la huella de iniciativas como la compilación de las Leges Palatinae o la creación del mausoleo real en la catedral de Mallorca han sido temas tratados por la misma autora. Cfr. M. SERRANO, "El arte áulico mallorquín y su reflejo en los proyectos artísticos de Pedro IV el Ceremonioso", XV Congreso Nacional de Historia del Arte (CEHA): Modelos, intercambios y recepción artística (de las rutas marítimas a la navegación en la red), Palma de Mallorca, 2008, vol. I, pp. 175-185.

58 Llompart y Escandell se desmarcan de las tradicionales -y casi siempre dubitativas- identificaciones con Jaime I o Jaime III, abogando "a favor d'una representació genèrica-sense identificació nominal precisa del rei de Mallorca", por una alusión "a un sobirà del regne de Mallorca atemporal". G. LLOMPART e I. ESCANDELL, op. cit., 2010, pp. 134-135.

59 F. SOLDEVILA (ed.), op. cit., 1971, p. 32.

60 La otra gran miniatura referida al Conquistador (f. 222v.) lo muestra sentado en un trono más discreto -de madera-, ligeramente vuelto hacia el obispo que sostiene los privilegios y con ángeles que flanquean "pasivamente" el trono; se trata pues de una representación menos ritual.

61 G. LLOMPART e I. ESCANDELL, op. cit., 2010, pp. 135. 
destacar que para los ilustradores no debía de ser fácil responder cumplidamente a las indicaciones de los ideólogos de las imágenes ni a las sutilezas del mensaje que éstos querían transmitir; imaginemos la dificultad de representar de manera explícita con los gestos de los personajes el matiz diferencial entre conceder y confirmar los privilegios $^{62}$. Salvando las distancias, tan solo el monarca reinante, Jaime III, recibe un trato similar: es representado entronizado, no con los atributos habituales de la realeza (el cetro y el pomo) sino con la cruz y una amenazante espada en la derecha, mientras dos ángeles le sujetan la corona, confirmando su rango de elegido y su legitimidad en un trono nuevamente amenazado.

Huelga decir que en un códice tan cortesano como el de las Leges, los mismos distintivos acaban por ser las auténticas insignias de la realeza. En la miniatura del frontispicio se han borrado los instrumentos que sujetaba el rey -tal vez un cetro y una cruz-; los militares llevan escudos y lanzas, mientras los eclesiásticos ostentan cruces astadas y báculos. Pero una imponente espada se alza a la derecha del rey, sobre uno de los reposabrazos. En la otra representación del consejo real (f. 56v.) ni el rey ni los eclesiásticos no se significan con unos atributos específicos; tan solo el brazo militar, sin su indumentaria característica, se muestra armado "para el combate" con tres desmesuradas espadas. Tal vez "los viejos y nuevos temores" a los que aludía B. Palacios resurgían amenazantes y el rey de Mallorca al menos quería desafiarlos "artísticamente".

Concientes, pues, de los peligros que constantemente acuciaban a su Corona, los monarcas aprovecharon el potencial simbólico de las artes en general para manifestar la plena soberanía real y se sirvieron de ellas como si se tratara de eficaces instrumentos para la construcción de una imagen del poder y para ostentar el prestigio y la fuerza del reino que se les había concedido. Y los jurados se aferraron igualmente al valor simbólico de la imagen al "sacralizar" al creador del reino, para así salvaguardar celosamente los privilegios adquiridos.

Todo iba a ser en vano. Se avecinaban tiempos difíciles. Precisamente en 1336 subía al trono de Aragón Pedro el Ceremonioso, el rey que usurparía la Corona de Mallorca. No iba a tardar en poner manos a la obra, pues a lo largo de la década de los cuarenta se apoderaría de todos los territorios y en 1349 daría muerte a Jaime III. $\mathrm{El}$ anterior esplendor y dinamismo de las construcciones áulicas entró en fase de recesión cuando Mallorca fue de nuevo reintegrada a la Corona aragonesa, cuyos confines territoriales eran mucho más dilatados. Necesariamente las exigencias edilicias y las iniciativas de promoción de obras artísticas se dispersaban; Perpiñán y Palma dejaban de ser los únicos centros de interés. Feneció así el Reino privativo, pero afortunadamente se salvaron sus obras, herencia de una dinastía que procuró por todos los medios crear los escenarios de su realeza, pero los reveses de la fortuna hicieron que tan solo por breve tiempo pudiera exhibir en ellos su dignidad.

62 El análisis de los gestos, de los atributos reales, de los modelos que pudieron servir a los pintores y del contexto histórico preciso en que se conciben estas imágenes requiere un argumentario más detallado que me propongo desarrollar en el futuro. 